\title{
New Insight in Cold Pain: Role of Ion Channels, Modulation, and Clinical Perspectives
}

\author{
DStéphane Lolignier, ${ }^{1,2}$ Dimitra Gkika, ${ }^{3}$-David Andersson, ${ }^{4}$ Enrico Leipold, ${ }^{5}$ Irina Vetter, ${ }^{6}$ Felix Viana, ${ }^{7}$ \\ - $J$ Jacques Noël, ${ }^{8,9}$ and ${ }^{-}$Jérôme Busserolles ${ }^{1,2}$ \\ ${ }^{1}$ Clermont Université, Université d'Auvergne, Pharmacologie fondamentale et clinique de la douleur, 63000 Clermont-Ferrand, France, ${ }^{2}$ Inserm, U 1107, \\ Neuro-Dol, 63000 Clermont-Ferrand, France, ${ }^{3}$ Laboratoire de Physiologie cellulaire, Inserm U1003, Laboratory of Excellence, Ion Channels Science and \\ Therapeutics, Université Lille 1, 59655 Villeneuve d'Ascq Cedex, France, ${ }^{4}$ King's College London, Wolfson Centre for Age-Related Diseases Wolfson Wing, \\ SE1 1UL London, United Kingdom, ${ }^{5}$ Institut für Biochemie und Biophysik, D-07745 Jena, Germany, ${ }^{6}$ Institute for Molecular Bioscience and School of \\ Pharmacy, University of Queensland, Brisbane, Queensland 4072, Australia, ${ }^{7}$ Instituto de Neurociencias de Alicante Universidad Miguel Hernandez/CSIC \\ Avda. S. Ramón y Cajal s.n. San Juan de Alicante, 03550 Alicante, Spain, ${ }^{8}$ Université Côte d'Azur, CNRS UMR 7275, Institut de Pharmacologie Moléculaire \\ et Cellulaire, France, and ${ }^{9}$ LabEx Ion Channel Science and Therapeutics, 06560 Valbonne, France
}

Cold temperature detection involves the process of sensory transduction in cutaneous primary sensory nerve terminals, which converts thermal stimuli into depolarizations of the membrane. This transformation into electrical signals is followed by the subsequent propagation of action potentials in cold-sensitive afferent nerve fibers. A large array of ion channels shapes this process; however, the precise contribution of specific ion channel subtypes to cold perception and cold pain remains elusive. This review aims at giving an update on our current understanding of the role played by TRPs, leak $\mathrm{K}^{+}$and voltage-gated $\mathrm{Na}^{+}$and $\mathrm{K}^{+}$channels in the transduction of cold by nociceptors and in cold-induced pain.

Key words: cold pain; ion channels; nociception

The perception of cold temperatures starts with the conversion of thermal stimuli into electrical signals by molecular transducers in the plasma membrane of primary sensory nerve terminals, a process known as sensory transduction. Some of the cold-sensitive nerve fibers detect moderate innocuous cold, whereas others detect noxious cold temperatures $\sim<19^{\circ} \mathrm{C}$ (Campero et al., 1996, 2001). Ultimately, the intensity and duration of the stimuli are coded into trains of action potentials by voltage-gated ion channels. A large array of ion channels, including thermo-sensitive Transient Receptor Potential (TRP), sodium and potassium channels shape this process. Our current understanding of the mechanisms of thermal transduction is fairly incomplete, especially the transduction of cold stimuli that appears to involve different cold transducers, some of which are yet to be identified, and other ion channels playing an indirect role in this process by setting the electrophysiological environment required by the transduction machinery. Pathological cold pain, a common symptom in a range of neuropathic pain syndromes, may also arise from dysfunctions of this transduction machinery, and presents as cold allodynia, a pain response to cold temperatures that do not normally provoke pain, and/or cold hyperalgesia, an increased sensitivity to painful cold temperature (Yin et al., 2015). The

Received July 22, 2016; revised Sept. 5, 2016; accepted Sept. 7, 2016.

The authors declare no competing financial interests.

Correspondence should be addressed to either of the following: Dr. Jérôme Busserolles, NEURO-DOL, Faculté de Médecine, 28 place Henri Dunant, BP 10448, F-63000, Clermont-Ferrand, France, E-mail: jerome.busserolles@udamail.fr; or Dr. Jacques Noël, IPMC, CNRS, 660 Route des Lucioles, 06560 Valbonne, France. E-mail: jnoel@unice.fr.

DOI:10.1523/JNEUROSCI.2327-16.2016

Copyright $\odot 2016$ the authors $\quad 0270-6474 / 16 / 3611435-05 \$ 15.00 / 0$ aim of this review is to provide an overview of our current knowledge about the contribution of specific ions channels to physiological and pathological cold transduction and cold-triggered pain, emphasizing on the recent progress made in the understanding of the identity and respective roles and regulation of these channels. New findings about the two thermo-TRP channels TRPM8 and TRPA1 recognized as involved in cold perception will be presented. The contribution of the voltage-gated sodium channel Nav1.9 to cold pain in animals and humans will also be described together with the wide diversity of potassium channels shown to be important for cold sensation. Finally, we will present how different cold pain conditions induced by toxins or chemotherapeutic agents altering cold sensitivity give us insight regarding cold transduction and cold pain sensation.

\section{Ion channels involved in the transduction of cold} temperature by nociceptors

TRP channels

TRP cation channel subfamily $M$ member 8 (TRPM8), the receptor for menthol, was the first cold-transducer channel to be described (McKemy et al., 2002; Peier et al., 2002). This nonselective cation channel is directly activated by innocuous cooling $\left(<28^{\circ} \mathrm{C}, \mathrm{Q}_{10}>20\right)$, and in vivo behavioral studies showed an involvement of TRPM8 channels in thermal discrimination $<25^{\circ} \mathrm{C}$ (Bautista et al., 2007; Colburn et al., 2007; Dhaka et al., 2007). More recent studies have also shown a role for TRPM8 channels and TRPM8-expressing neurons in cold-triggered nociception (Knowlton et al., 2011; Pogorzala et al., 2013). Although TRPM8 involvement in non-noxious thermal discrim- 
ination $<25^{\circ} \mathrm{C}$ is undisputable, its involvement in cold-triggered nociception remains debated (Yin et al., 2015). Whereas TRPM8 activation by cold as well as by exogenous substances such as menthol have been the matter of extensive studies (Almaraz et al., 2014), endogenous activators or inhibitors of TRPM8 have more rarely been identified. Interestingly, it was shown previously that androgens increase TRPM8 expression in non-neural cells (L. Zhang and Barritt, 2004; Y. Zhang et al., 2004; Thebault et al., 2005). In addition to this genomic regulation by androgens, testosterone acts directly on the TRPM8 channel at subphysiological concentrations (Asuthkar et al., 2015), and recent unpublished work also shows that, in the presence of the androgen receptor, physiological concentration of testosterone specifically inhibits TRPM8 activity in transfected cells and primary sensory neurons through direct interaction of the channel with the androgen receptor at the plasma membrane. Most interestingly, in vivo experiments show that androgens reduce male sensitivity to non-noxious cold temperatures through a TRPM8-dependent mechanism (D.G. et al., unpublished data). This may be consistent with the notion that elevated plasma levels of testosterone, which usually accompany mating behaviors, physical activity, stress, or aggression, by desensitizing TRPM8 would help to diminish the impact of environmental cold as a factor that may impede taking necessary actions.

The TRP cation channel subfamily A member 1 (TRPA1), or ANKTM1, is another thermo-TRP channel expressed in nociceptive DRGs and trigeminal neurons. TRPA1 is activated by pungent compounds and was initially characterized as a coldsensitive ion channel (Story et al., 2003), but this has remained contentious ever since, with a number of studies presenting supporting (Fajardo et al., 2008; Karashima et al., 2009; Moparthi et al., 2014) or conflicting evidence (Jordt et al., 2004; McKemy, 2005; Bautista et al., 2006; Knowlton et al., 2010). However, pharmacological inhibition or genetic inactivation of TRPA1 clearly revealed the importance of TRPA1 for the behavioral response to noxious cold $\left(\leq 5^{\circ} \mathrm{C}\right)$ in vivo (Kwan et al., 2006; Karashima et al., 2009; Gentry et al., 2010). In contrast, the absence of TRPA1 does not influence the behavior of mice in thermal preference tests designed to evaluate comfort temperature preferences (Knowlton et al., 2010), suggesting that TRPA1 most specifically controls the responsiveness to noxious cold, but not to innocuous cool. Several reports have also identified TRPA1 as a physiological sensor of critical importance for cold hypersensitivity associated with inflammatory and neuropathic pain (Zygmunt and Högestätt, 2014). Recent unpublished observations suggest a novel mechanism for TRPA1 regulation of cold nociception and cold pain. It is hypothesized that TRPA1 regulates cold sensitivity in vivo indirectly, rather than by simply acting as a sensory transduction molecule (D.A. et al., unpublished data).

The discovery of the cold-triggered activation of the TRP cation channel subfamily C member 5 (TRPC5) has expanded the list of cold-sensitive TRP channels expressed in DRG neurons (Zimmermann et al., 2011). However, it is not clear whether TRPC5 plays a role in somatosensory cold sensation as, although $T R P C 5^{-1-}$ fibers have an increased responsiveness to cooling, TRPC $5^{-/-}$mice show normal response to noxious cold and cold preference over wild-type mice.

These findings also point to another aspect of cold transduction by DRG neurons because $30 \%-50 \%$ of isolated DRG neurons in culture are sensitive to cold but unresponsive to either agonists of TRPA1 or TRPM8, indicating that a fraction of sensory neurons most probably relies on a different, yet unidentified, mechanism to transduce cold stimuli (Alloui et al., 2006; Munns et al., 2007).

\section{Potassium channels}

Potassium channels are hyperpolarizing inhibitory channels and therefore key determinants of neuronal excitability, regulating resting membrane potential, spike threshold and duration, and repetitive firing activity. Primary sensory neurons express a complex complement of potassium channels that modulates their transducing properties and shape their excitability (Gold et al., 1996; Belmonte and Viana, 2008; Tsantoulas and McMahon, 2014). The diversity of $\mathrm{K}^{+}$channels expressed in DRG neurons was confirmed at the single-cell transcriptome level (Usoskin et al., 2015). A number of studies have highlighted the role of different potassium channels in the modulation of cold sensitivity (for review, see Belmonte and Viana, 2008). Their expression and function change following neuronal injury, which contributes to nociceptors hyperexcitability and pain symptoms, such as mechanical and cold allodynia (Chien et al., 2007; Descoeur et al., 2011; Pollema-Mays et al., 2013; Pereira et al., 2014; Tsantoulas and McMahon, 2014).

Among the different families of $\mathrm{K}^{+}$channels, several members of the KCNK channel family, also known as 2-pore domain $\left(\mathrm{K}_{2 \mathrm{P}}\right)$ potassium channels, were found to play a key modulatory role in cold sensation. These channels mediate voltage-independent background leak $\mathrm{K}^{+}$currents and participate in setting the resting membrane potential of many neurons (Chemin et al., 2003). There are 15 members of this family, with different biophysical properties and distinct expression profiles in sensory neurons (Mathie and Veale, 2015). Some of these channels (e.g., TREK-1, TREK-2, and TRAAK) are highly temperature-sensitive (Maingret et al., 2000; Kang et al., 2005). Analysis of TREK and TRAAK deficient mice suggests their participation in nociception and thermal sensitivity (Alloui et al., 2006; Noël et al., 2009; Pereira et al., 2014). More specifically, TREK2 $2^{-/-}$mice show enhanced responses to moderate cold temperatures but no signs of abnormal cold pain. In contrast, TREK1 ${ }^{-/-}$and TRAAK ${ }^{-/-}$ mice have augmented responses to noxious cold. The expression of TREK1, TREK2, and TRAAK channels in DRGs was also found to be diminished in a mice model of neuropathic cold hypersensitivity induced by the antineoplastic agent oxaliplatin (Descoeur et al., 2011; Pereira et al., 2014). Thus, in some forms of neuropathic pain conditions, reduced background potassium activity may contribute to heightened cold sensitivity.

Transcriptome analysis of fluorescent-activated cell sorting of TRPM8-expressing mouse cold thermoreceptors revealed the differential expression of TASK-3, a $\mathrm{pH}$-sensitive $\mathrm{K}_{2 \mathrm{P}}$ leak channel, a finding confirmed by immunocytochemistry and RT-PCR (Morenilla-Palao et al., 2014). Application of a selective TASK-3 blocker shifted the temperature threshold of cold-sensitive TRPM8expressing DRG neurons to warmer temperatures. Moreover, analysis of cold thermoreceptors in TASK-3 KO mice revealed a higher sensitivity to cooling and augmented responses to electrical and thermal stimulations. This argues that combinatorial expression of cold-sensitive hyperpolarizing and depolarizing channels in primary sensory nerve terminals can lead to functional diversity.

The voltage-gated potassium channels Kv1 and Kv7.2/7.3 have been implicated in the physiology of cold sensing and in the pathophysiology of cold pain. In TRPM8-expressing cold-sensitive neurons, differential expression of a fast activating, slowly inactivating, dendrotoxin- and 4-aminopyridine-sensitive, voltage-gated $\mathrm{K}^{+}$ current (Kv1.1 and Kv1.2 subunits), known as IKD, plays a major role in modulating threshold temperatures to cold stimuli (Madrid 
et al., 2009). Activation of IKD dampens the depolarizing effect of the cold-activated TRPM8-dependent current, shifting the temperature thresholds of individual neurons to colder values and reducing their overall response to temperature drops. In a fraction of sensory neurons, application of micromolar doses of 4-aminopyridine can transform their functional phenotype leading to abnormal cold sensitivity (Belmonte and Viana, 2008), an effect also found in intact and damaged peripheral sensory axons (Roza et al., 2006). Moreover, after local blockade of IKD in the hindpaw of mice, normally innocuous cool stimuli elicited nociceptive behaviors, suggesting that IKD acts as a brake to cold sensitivity in vivo (Madrid et al., 2009). Thus, IKD sharpens the tuning of sensory neurons to relevant stimuli.

KCNQ channels Kv7.2/3, the molecular components of the $\mathrm{M}$-current, also modulate the response of nociceptors to cold in synergy with TRPM8 channels. Indeed, pharmacological blockade of the M-current increases the excitability of a large fraction of $\mathrm{C}$ fibers in response to cold, in which TRPM8 channels activation is required (Vetter et al., 2013). Sensitization of nociceptors to cold by the cooling agents camphor or menthol has also been shown to involve concomitant Kv7.2/3 blockade and TRPM8 activation.

\section{Voltage-gated sodium channels}

Nav1.7, Nav1.8, and Nav1.9 are the most abundant voltagedependent $\mathrm{Na}^{+}$channel isoforms in peripheral afferent fibers. Genetic variants of these channels are associated with a spectrum of distinct inherited pain disorders, ranging from congenital pain insensitivity to severe neuropathic pain syndromes. Two of these voltage-gated $\mathrm{Na}^{+}$channels, the tetrodotoxin-resistant Nav1.8 and Nav1.9 channels, are expressed in nociceptors and involved in the response of cold-sensitive fibers to noxious cold. The inactivation properties of Nav1.8 and Nav 1.9 channels are less affected by cooling than the tetrodotoxin-sensitive channels, which makes them able to contribute to action potentials initiation in cold-sensitive fibers at low temperatures.

Nav1.8 is important for nociceptors' ability to remain excitable at low temperature, whereas the cold-induced inactivation of other channels in other afferent fibers appears to contribute to the loss of other sensory modalities (numbness) observed with cooling of peripheral tissues (Zimmermann et al., 2007). Genetic ablation of Nav1.8 in mice results, among other impairments of pain sensitivity, in a decreased sensitivity to noxious cold (Akopian et al., 1999; Zimmermann et al., 2007).

The ultra-slow inactivating tetrodotoxin-resistant Nav1.9 channel, whose expression pattern largely overlaps with Nav1.8 in DRG neurons, has also recently been found to be resistant to cooling and to be involved in the painful response to cold (Lolignier et al., 2015). Nav1.9 $9^{-/-}$mice have an increased tolerance to noxious cold (from $\leq 12^{\circ} \mathrm{C}$ ) and nociceptors from Nav1.9 mice show a decreased activation in response to cooling. In coldsensitive nociceptors, specifically, a strong increase in Nav1.9 current was observed. This increased inward $\mathrm{Na}^{+}$current is necessary for the firing of cold-sensitive neurons in response to cooling, in which the large and persistent Nav1.9 current amplifies depolarizations generated by cold transducer channels. The identity of the cold transducer channel(s) expressed by Nav1.9positive/cold-responding sensory fibers is however still unclear as the vast majority of these fibers appear not to express TRPM8 or TRPA1. Nav1.9 is also involved in cold hypersensitivity in mice (at $15^{\circ} \mathrm{C}-20^{\circ} \mathrm{C}$ ) following treatment with oxaliplatin. This places Nav1.9, together with Nav1.8, at the center of physiological and pathological painful responses to cold. These two channels, to- gether with leak and voltage-gated potassium channels, would provide an ideal electrophysiological environment for the coding and transmission of cold nociceptive information.

Inherited pain disorders associated with Nav1.9 genetic variants Chronic pain syndromes associated with the Nav isoforms Nav1.7, 1.8, and 1.9, include primary erythromelalgia, paroxysmal extreme pain disorder (PEPD), and small-fiber neuropathies (Dib-Hajj et al., 2010). In particular, Nav1.7-dependent primary erythromelalgia, a condition characterized by severe pain attacks preferentially in the lower legs and arms as well as in the adjacent joints, is recognized for its marked temperature dependence because warmth is often a strong trigger for painful episodes and exacerbates symptoms while patients consistently experience pain relief on cooling of affected body areas.

A heterozygous gain-of-function mutation in SCN11A, caused by the missense mutation p.V1184A in Nav1.9 channels, has recently been identified in a family with a history of earlyonset chronic peripheral pain (Leipold et al., 2015). Affected family members suffer from pain attacks in their lower and upper extremities lasting $\sim 20-30 \mathrm{~min}$, which are reminiscent of erythromelalgia-associated pain episodes caused by hyperactive Nav1.7 channels. However, patients exhibit a reversed temperature sensitivity of pain sensation because pain is aggravated by cold and partially relieved by warmth. Electrophysiological evaluation of heterologously expressed Nav1.9-V1184A channels revealed that the mutation increases the basal activity of Nav1.9 such that mutant channels require less depolarization to open, effectively increasing the fraction of active mutant channels. In agreement with these gain-of-function features, mutant channels increase the resting membrane potential of murine DRG neurons and subsequently render the neurons hyperexcitable. A reduced cold-dependent attenuation of the excitability of neurons transfected with p.V1184A compared with neurons transfected with wild-type Nav1.9 was observed, which is in line with the temperature dependence of the patients' pain sensation and suggests that the contribution of hyperactive Nav1.9-V1184A channels to nociceptors excitability is more prominent at lower temperatures. Thus, this study corroborates the link between Nav1.9 and coldpain sensation initially demonstrated by Lolignier et al. (2015). However, the intrinsic temperature dependence of Nav1.9 was not affected by mutation p.V1184A, suggesting that the role of Nav1.9 in cold pain requires additional cellular factors. As discussed in the previous paragraph, yet unidentified cold transducers are possible candidate proteins. According to Lolignier et al. (2015), Nav1.9 acts as an amplifier of cold transducer subthreshold signals. Hyperactive Nav1.9-V1184A mutant channels may as a consequence cause cold-aggravated peripheral pain by signal overamplification in cold-sensitive nociceptors.

\section{Pathological cold pain conditions}

Although many pathological pain conditions, including diabetic neuropathy, peripheral nerve injury, chemotherapy-induced neuropathy, poststroke central pain, or ciguatera poisoning, can result in the development of cold pain, the mechanisms by which cold pain arises are still poorly understood and appear to vary significantly in relation to the disease considered (for review, see Yin et al., 2015).

The mechanisms of action of toxins altering cold sensitivity give us insight regarding cold transduction beyond those provided by animals or humans harboring mutant channels. Pathological cold pain is a frequent symptom of ciguatera poisoning, a form of marine food poisoning arising from the consumption of 
tropical and subtropical fish contaminated with ciguatoxins from microscopic algae of the Gambierdiscus family accumulated through the marine food chain. Ingestion of contaminated fish causes symptoms of dysaesthesias, paresthesias, and cold allodynia in almost all ciguatera patients (Vetter et al., 2014). At the molecular level, ciguatoxins are the most potent known sodium channel activators and additionally enhance neuronal excitability through inhibition of potassium channels. It is now clear that the pathophysiological effects of ciguatoxins can be attributed directly to their action on peripheral sensory neurons, as local intradermal injection in humans recapitulates spontaneous pain and cold allodynia (Zimmermann et al., 2013). Similar symptoms can be observed after intraplantar injection in mice, an effect that is mediated predominantly through peripheral sensory neurons expressing TRPA1 (Vetter et al., 2012). Ciguatoxininduced cold allodynia can additionally be blocked by concomitant treatment with selective Nav1.8 and Nav1.6 inhibitors, consistent with profound effects on excitability of nociceptive C- and A-fibers, respectively.

In contrast to ciguatera poisoning, cold allodynia elicited after local injection of the chemotherapeutic agent oxaliplatin is unchanged in Nav1.8 KO mice and develops independently from cold-sensitive TRP channels (Deuis et al., 2013). Oxaliplatininduced cold allodynia is blocked completely by the selective Nav1.6 inhibitor GIIIA, suggesting a specific role for Nav1.6-expressing sensory neurons in oxaliplatin-induced cold allodynia. However, Nav1.6-expressing neurons seem not to be involved in physiological cold sensation because intraplantar administration of the Nav1.6selective activator $\mathrm{Cn} 2$ elicits spontaneous pain and mechanical allodynia but does not enhance cold sensitivity. Conversely, intraplantar administration of the $\mathrm{K}^{+}$channel blocker 4-aminopyridine mimicks oxaliplatin-induced cold allodynia, which is inhibited by Nav1.6 blockers and potentiated by Nav1.6 activators (Deuis et al., 2013). Therefore, it appears that inhibition of neuronal $\mathrm{K}^{+}$channels is a common mechanism underpinning the development of enhanced cold sensitivity in both ciguatoxin- and oxaliplatininduced cold allodynia. Although the precise mechanisms leading to specific changes in cold sensitivity remain to be determined, it is likely that this effect arises at least in part from biophysical changes induced by cooling, which include a decrease in the activation threshold of the sodium currents, an increase in membrane resistance, and closure of temperature-sensitive background potassium channels. In normally cold-insensitive neurons, these effects are opposed by the continued activity of temperature-insensitive $\mathrm{K}^{+}$channels, which act as an excitability break. Pharmacological inhibition, or reduced expression, of these channels can in turn drive normally cold-insensitive neurons to respond to cooling, although it remains to be determined whether temperature-sensitive TRP channels are an absolute requirement for this phenomenon. Although these channels likely include Kv1.1 in some types of neurons, the molecular identity of the $\mathrm{K}^{+}$channels contributing to cold sensitivity of Nav1.6-expressing neurons remains to be determined.

In conclusion, these recent findings highlight the complexity of cold transduction and coding of cold stimuli by sensory nerve fibers. An array of ion channels is involved in physiological cold sensation and pain and in pathological cold-pain states, either directly or through the tuning of the electrophysiological properties of the cell membrane. The molecular mechanisms of cold hypersensitivity, such as allodynia, affect multiple ion channels and pathways in different ways depending on the pathology in place, even when they look very similar or indistinguishable at the phenotypic level.

\section{References}

Akopian AN, Souslova V, England S, Okuse K, Ogata N, Ure J, Smith A, Kerr BJ, McMahon SB, Boyce S, Hill R, Stanfa LC, Dickenson AH, Wood JN (1999) The tetrodotoxin-resistant sodium channel SNS has a specialized function in pain pathways. Nat Neurosci 2:541-548. CrossRef Medline

Alloui A, Zimmermann K, Mamet J, Duprat F, Noël J, Chemin J, Guy N, Blondeau N, Voilley N, Rubat-Coudert C, Borsotto M, Romey G, Heurteaux C, Reeh P, Eschalier A, Lazdunski M (2006) TREK-1, a K ${ }^{+}$channel involved in polymodal pain perception. EMBO J 25:2368-2376. CrossRef Medline

Almaraz L, Manenschijn JA, de la Peña E, Viana F (2014) TRPM8. Handb Exp Pharmacol 222:547-579. CrossRef Medline

Asuthkar S, Elustondo PA, Demirkhanyan L, Sun X, Baskaran P, Velpula KK, Thyagarajan B, Pavlov EV, Zakharian E (2015) The TRPM8 protein is a testosterone receptor: I. Biochemical evidence for direct TRPM8testosterone interactions. J Biol Chem 290:2659-2669. CrossRef Medline

Bautista DM, Jordt SE, Nikai T, Tsuruda PR, Read AJ, Poblete J, Yamoah EN, Basbaum AI, Julius D (2006) TRPA1 mediates the inflammatory actions of environmental irritants and proalgesic agents. Cell 124:1269-1282. CrossRef Medline

Bautista DM, Siemens J, Glazer JM, Tsuruda PR, Basbaum AI, Stucky CL, Jordt SE, Julius D (2007) The menthol receptor TRPM8 is the principal detector of environmental cold. Nature 448:204-208. CrossRef Medline

Belmonte C, Viana F (2008) Molecular and cellular limits to somatosensory specificity. Mol Pain 4:14. CrossRef Medline

Campero M, Serra J, Ochoa JL (1996) C-polymodal nociceptors activated by noxious low temperature in human skin. J Physiol 497:565572. CrossRef Medline

Campero M, Serra J, Bostock H, Ochoa JL (2001) Slowly conducting afferents activated by innocuous low temperature in human skin. J Physiol 535:855-865. CrossRef Medline

Chemin J, Girard C, Duprat F, Lesage F, Romey G, Lazdunski M (2003) Mechanisms underlying excitatory effects of group I metabotropic glutamate receptors via inhibition of $2 \mathrm{P}$ domain $\mathrm{K}^{+}$channels. EMBO J 22: 5403-5411. CrossRef Medline

Chien LY, Cheng JK, Chu D, Cheng CF, Tsaur ML (2007) Reduced expression of A-type potassium channels in primary sensory neurons induces mechanical hypersensitivity. J Neurosci 27:9855-9865. CrossRef Medline

Colburn RW, Lubin ML, Stone DJ Jr, Wang Y, Lawrence D, D'Andrea MR, Brandt MR, Liu Y, Flores CM, Qin N (2007) Attenuated cold sensitivity in TRPM8 null mice. Neuron 54:379-386. CrossRef Medline

Descoeur J, Pereira V, Pizzoccaro A, Francois A, Ling B, Maffre V, Couette B, Busserolles J, Courteix C, Noel J, Lazdunski M, Eschalier A, Authier N, Bourinet E (2011) Oxaliplatin-induced cold hypersensitivity is due to remodelling of ion channel expression in nociceptors. EMBO Mol Med 3:266-278. CrossRef Medline

Deuis JR, Zimmermann K, Romanovsky AA, Possani LD, Cabot PJ, Lewis RJ, Vetter I (2013) An animal model of oxaliplatin-induced cold allodynia reveals a crucial role for Nav1.6 in peripheral pain pathways. Pain 154: 1749-1757. CrossRef Medline

Dhaka A, Murray AN, Mathur J, Earley TJ, Petrus MJ, Patapoutian A (2007) TRPM8 is required for cold sensation in mice. Neuron 54:371-378. CrossRef Medline

Dib-Hajj SD, Cummins TR, Black JA, Waxman SG (2010) Sodium channels in normal and pathological pain. Annu Rev Neurosci 33:325-347. CrossRef Medline

Fajardo O, Meseguer V, Belmonte C, Viana F (2008) TRPAl channels mediate cold temperature sensing in mammalian vagal sensory neurons: pharmacological and genetic evidence. J Neurosci 28:7863-7875. CrossRef Medline

Gentry C, Stoakley N, Andersson DA, Bevan S (2010) The roles of iPLA2, TRPM8 and TRPA1 in chemically induced cold hypersensitivity. Mol Pain 6:4. CrossRef Medline

Gold MS, Shuster MJ, Levine JD (1996) Characterization of six voltagegated $\mathrm{K}^{+}$currents in adult rat sensory neurons. J Neurophysiol 75:26292646. Medline

Jordt SE, Bautista DM, Chuang HH, McKemy DD, Zygmunt PM, Högestätt ED, Meng ID, Julius D (2004) Mustard oils and cannabinoids excite sensory nerve fibres through the TRP channel ANKTM1. Nature 427: 260-265. CrossRef Medline

Kang D, Choe C, Kim D (2005) Thermosensitivity of the two-pore domain 
$\mathrm{K}^{+}$channels TREK-2 and TRAAK. J Physiol 564:103-116. CrossRef Medline

Karashima Y, Talavera K, Everaerts W, Janssens A, Kwan KY, Vennekens R, Nilius B, Voets T (2009) TRPAl acts as a cold sensor in vitro and in vivo. Proc Natl Acad Sci U S A 106:1273-1278. CrossRef Medline

Knowlton WM, Bifolck-Fisher A, Bautista DM, McKemy DD (2010) TRPM8, but not TRPA1, is required for neural and behavioral responses to acute noxious cold temperatures and cold-mimetics in vivo. Pain 150: 340-350. CrossRef Medline

Knowlton WM, Daniels RL, Palkar R, McCoy DD, McKemy DD (2011) Pharmacological blockade of TRPM8 ion channels alters cold and cold pain responses in mice. PLoS One 6:e25894. CrossRef Medline

Kwan KY, Allchorne AJ, Vollrath MA, Christensen AP, Zhang DS, Woolf CJ, Corey DP (2006) TRPAl contributes to cold, mechanical, and chemical nociception but is not essential for hair-cell transduction. Neuron 50: 277-289. CrossRef Medline

Leipold E, Hanson-Kahn A, Frick M, Gong P, Bernstein JA, Voigt M, Katona I, Oliver Goral R, Altmüller J, Nürnberg P, Weis J, Hübner CA, Heinemann SH, Kurth I (2015) Cold-aggravated pain in humans caused by a hyperactive NaV1.9 channel mutant. Nat Commun 6:10049. CrossRef Medline

Lolignier S, Bonnet C, Gaudioso C, Noël J, Ruel J, Amsalem M, Ferrier J, Rodat-Despoix L, Bouvier V, Aissouni Y, Prival L, Chapuy E, Padilla F, Eschalier A, Delmas P, Busserolles J (2015) The Nav1.9 channel is a key determinant of cold pain sensation and cold allodynia. Cell Rep 11:10671078. CrossRef Medline

Madrid R, de la Peña E, Donovan-Rodriguez T, Belmonte C, Viana F (2009) Variable threshold of trigeminal cold-thermosensitive neurons is determined by a balance between TRPM8 and Kv1 potassium channels. J Neurosci 29:3120-3131. CrossRef Medline

Maingret F, Lauritzen I, Patel AJ, Heurteaux C, Reyes R, Lesage F, Lazdunski M, Honoré E (2000) TREK-1 is a heat-activated background $\mathrm{K}(+)$ channel. EMBO J 19:2483-2491. CrossRef Medline

Mathie A, Veale EL (2015) Two-pore domain potassium channels: potential therapeutic targets for the treatment of pain. Pflugers Arch 467:931-943. CrossRef Medline

McKemy DD (2005) How cold is it? TRPM8 and TRPA1 in the molecular logic of cold sensation. Mol Pain 1:16. CrossRef Medline

McKemy DD, Neuhausser WM, Julius D (2002) Identification of a cold receptor reveals a general role for TRP channels in thermosensation. Nature 416:52-58. CrossRef Medline

Moparthi L, Survery S, Kreir M, Simonsen C, Kjellbom P, Högestätt ED, Johanson U, Zygmunt PM (2014) Human TRPA1 is intrinsically coldand chemosensitive with and without its $\mathrm{N}$-terminal ankyrin repeat domain. Proc Natl Acad Sci U S A 111:16901-16906. CrossRef Medline

Morenilla-Palao C, Luis E, Fernández-Peña C, Quintero E, Weaver JL, Bayliss DA, Viana F (2014) Ion channel profile of TRPM8 cold receptors reveals a role of TASK-3 potassium channels in thermosensation. Cell Rep 8:1571-1582. CrossRef Medline

Munns C, AlQatari M, Koltzenburg M (2007) Many cold sensitive peripheral neurons of the mouse do not express TRPM8 or TRPA1. Cell Calcium 41:331-342. CrossRef Medline

Noël J, Zimmermann K, Busserolles J, Deval E, Alloui A, Diochot S, Guy N, Borsotto M, Reeh P, Eschalier A, Lazdunski M (2009) The mechanoactivated $\mathrm{K}^{+}$channels TRAAK and TREK- 1 control both warm and cold perception. EMBO J 28:1308-1318. CrossRef Medline

Peier AM, Moqrich A, Hergarden AC, Reeve AJ, Andersson DA, Story GM, Earley TJ, Dragoni I, McIntyre P, Bevan S, Patapoutian A (2002) A TRP channel that senses cold stimuli and menthol. Cell 108:705-715. CrossRef Medline

Pereira V, Busserolles J, Christin M, Devilliers M, Poupon L, Legha W, Alloui A, Aissouni Y, Bourinet E, Lesage F, Eschalier A, Lazdunski M, Noël J (2014) Role of the TREK2 potassium channel in cold and warm thermosensation and in pain perception. Pain 155:2534-2544. CrossRef Medline
Pogorzala LA, Mishra SK, Hoon MA (2013) The cellular code for mammalian thermosensation. J Neurosci 33:5533-5541. CrossRef Medline

Pollema-Mays SL, Centeno MV, Ashford CJ, Apkarian AV, Martina M (2013) Expression of background potassium channels in rat DRG is cellspecific and down-regulated in a neuropathic pain model. Mol Cell Neurosci 57:1-9. CrossRef Medline

Roza C, Belmonte C, Viana F (2006) Cold sensitivity in axotomized fibers of experimental neuromas in mice. Pain 120:24-35. CrossRef Medline

Story GM, Peier AM, Reeve AJ, Eid SR, Mosbacher J, Hricik TR, Earley TJ, Hergarden AC, Andersson DA, Hwang SW, McIntyre P, Jegla T, Bevan S, Patapoutian A (2003) ANKTM1, a TRP-like channel expressed in nociceptive neurons, is activated by cold temperatures. Cell 112:819-829. CrossRef Medline

Thebault S, Lemonnier L, Bidaux G, Flourakis M, Bavencoffe A, Gordienko D, Roudbaraki M, Delcourt P, Panchin Y, Shuba Y, Skryma R, Prevarskaya N (2005) Novel role of cold/menthol-sensitive transient receptor potential melastatine family member 8 (TRPM8) in the activation of store-operated channels in LNCaP human prostate cancer epithelial cells. J Biol Chem 280:39423-39435. CrossRef Medline

Tsantoulas C, McMahon SB (2014) Opening paths to novel analgesics: the role of potassium channels in chronic pain. Trends Neurosci 37:146-158. CrossRef Medline

Usoskin D, Furlan A, Islam S, Abdo H, Lönnerberg P, Lou D, Hjerling-Leffler J, Haeggström J, Kharchenko O, Kharchenko PV, Linnarsson S, Ernfors P (2015) Unbiased classification of sensory neuron types by large-scale single-cell RNA sequencing. Nat Neurosci 18:145-153. CrossRef Medline

Vetter I, Touska F, Hess A, Hinsbey R, Sattler S, Lampert A, Sergejeva M, Sharov A, Collins LS, Eberhardt M, Engel M, Cabot PJ, Wood JN, Vlachová V, Reeh PW, Lewis RJ, Zimmermann K (2012) Ciguatoxins activate specific cold pain pathways to elicit burning pain from cooling. EMBO J 31:3795-3808. CrossRef Medline

Vetter I, Hein A, Sattler S, Hessler S, Touska F, Bressan E, Parra A, Hager U, Leffler A, Boukalova S, Nissen M, Lewis RJ, Belmonte C, Alzheimer C, Huth T, Vlachova V, Reeh PW, Zimmermann K (2013) Amplified cold transduction in native nociceptors by M-channel inhibition. J Neurosci 33:16627-16641. CrossRef Medline

Vetter I, Zimmermann K, Lewis RJ (2014) Ciguatera toxins: pharmacology, toxicology, and detection. In: Seafood and freshwater toxins, pp 925-950. Boca Raton, FL: CRC.

Yin K, Zimmermann K, Vetter I, Lewis RJ (2015) Therapeutic opportunities for targeting cold pain pathways. Biochem Pharmacol 93:125-140. CrossRef Medline

Zhang L, Barritt GJ (2004) Evidence that TRPM8 is an androgen-dependent $\mathrm{Ca}^{2+}$ channel required for the survival of prostate cancer cells. Cancer Res 64:8365-8373. CrossRef Medline

Zhang Y, Butelman ER, Schlussman SD, Ho A, Kreek MJ (2004) Effect of the endogenous kappa opioid agonist dynorphin $\mathrm{A}(1-17)$ on cocaine-evoked increases in striatal dopamine levels and cocaine-induced place preference in C57BL/6J mice. Psychopharmacology (Berl) 172:422-429. CrossRef Medline

Zimmermann K, Leffler A, Babes A, Cendan CM, Carr RW, Kobayashi J, Nau C, Wood JN, Reeh PW (2007) Sensory neuron sodium channel Nav1.8 is essential for pain at low temperatures. Nature 447:855-858. CrossRef Medline

Zimmermann K, Lennerz JK, Hein A, Link AS, Kaczmarek JS, Delling M, Uysal S, Pfeifer JD, Riccio A, Clapham DE (2011) Transient receptor potential cation channel, subfamily C, member 5 (TRPC5) is a coldtransducer in the peripheral nervous system. Proc Natl Acad Sci U S A 108:18114-18119. CrossRef Medline

Zimmermann K, Deuis JR, Inserra MC, Collins LS, Namer B, Cabot PJ, Reeh PW, Lewis RJ, Vetter I (2013) Analgesic treatment of ciguatoxininduced cold allodynia. Pain 154:1999-2006. CrossRef Medline

Zygmunt PM, Högestätt ED (2014) TRPA1. In: Mammalian transient receptor potential (TRP) cation channels (Nilius B, Flockerzi V, eds), pp 583-630 Handbook of experimental pharmacology. Berlin: Springer. 